\title{
Water Allocation With Use of the Building Block Methodology (BBM) in the Godavari Basin, India
}

\author{
Tor Haakon Bakken ${ }^{1,2}$, Eva Skarbøvik ${ }^{3}$, A. K. Gosain ${ }^{4}$, K. Palanisami ${ }^{5}$, Julian Sauterleute ${ }^{1}$, Helene Egeland ${ }^{5}$, K. \\ R. Kakumanu ${ }^{5}$, Nagothu Udaya Sekhar ${ }^{3}$, Atle Harby ${ }^{1}$, K. Tirupataiah $^{7} \&$ Per Stålnacke $^{3}$ \\ ${ }^{1}$ SINTEF Energy Research, Trondheim, Norway \\ ${ }^{2}$ Norwegian University of Science and Technology, Trondheim, Norway \\ ${ }^{3}$ Bioforsk, F. A Dahls vei 20, 1432 Ås, Norway \\ ${ }^{4}$ Indian Institute of Technology Dehli, Hauz Khas, New-Dehli, India \\ ${ }^{5}$ IWMI International Water Management Institute, C/O ICRISAT, Patancheru, Andhra Pradesh, India \\ ${ }^{6}$ SINTEF Energy Research, Forskningsveien 3B, Pb 124 Blindern, Oslo, Norway \\ ${ }^{7}$ WALAMTARI, Rajendranagar, Himayat Sagar, Hyderabad, India \\ Correspondence: Tor Haakon Bakken, SINTEF Energy Research, Sem Sælands vei 11, NO-7465 Trondheim, \\ Norway. Tel: 47-9515-6944. E-mail: tor.haakon.bakken@sintef.no
}

Received: May 28, 2013 Accepted: July 12, 2013 Online Published: July 23, 2013

doi:10.5539/jsd.v6n8p93 URL: http://dx.doi.org/10.5539/jsd.v6n8p93

\begin{abstract}
Access to sufficient quantities of water of acceptable quality is a basic need for human beings and a pre-requisite to sustain and develop human welfare. In cases of limited availability, the allocation of water between different sectors can result in conflicts of interests. In this study, a modified version of the Building Block Methodology (BBM) was demonstrated for allocation of waters between different sectors. The methodology is a workshop-based tool for assessing water allocation between competing sectors that requires extensive stakeholder involvement. The tool was demonstrated for allocation of water in the Sri Ram Sagar water reservoir in the Godavari Basin, Andhra Pradesh, India. In this multipurpose reservoir, water is used for irrigation, drinking water supply and hydropower production. Possible water allocation regimes were developed under present hydrological conditions (normal and dry years) and under future climate change, characterized by more rain in the rainy season, more frequent droughts in the dry season and accelerated siltation of the reservoir, thus reducing the storage capacity. The feedback from the stakeholders (mainly water managers representing the various sectors) showed that the modified version of the BBM was a practical and useful tool in water allocation, which means that it may be a viable tool for application also elsewhere.
\end{abstract}

Keywords: optimal water allocation, building block methodology (BBM), climate change, Godavari Basin, India

\section{Introduction}

Water is essential for all types of basic services, such as food production, supply of drinking water, health and sanitation services, industrial production and for sustaining the earth's ecosystems. In India, investments in the water sector have primarily focused on irrigation projects with the aim to expand the area under irrigated agriculture and increase the food production. Other sectors also experience growing needs, such as drinking water supply, process-water to the industry, water for hydropower production, water to secure navigation and for recreational services (Amerasinghe et al., 2005; Chitale, 2005). There are also inherent dependencies between some of the water uses, exemplified by the fact that the majority of irrigation projects in India have provisions for generation of power. The availability of water is to a large extent dependent on climatological and hydrological characteristics, and the water resources in India are not evenly distributed in time and space (Gosain et al., 2006; Kakumanu, 2009). One part of the country might experience floods and water logging problems, while other parts might need to cope with droughts and scarcity at the same time. In periods when the need for water is larger than the supply, practical tools to assist in the allocation of water between competing sectors can be useful. Such tools may also reduce the tension between the different interests. 
The water management in India is primarily the responsibility of the states. The State Water Policies, alongside the National Water Policy, are the instruments that spell out water management practices. Policy making, water allocation, operation and maintenance of irrigation canals are carried out by the respective state governments. The Constitution at the national level provides certain powers to the Government of India (GOI) in case of trans-boundary river issues wherein tribunals are set up to resolve inter-state issues in water allocation. GOI also provides technical support to the states during extreme weather, including droughts as well as floods.

The majority of the states have drinking water as the top priority, followed by irrigation, hydropower generation, industry, fisheries and environmental flows. The states have different mechanisms to allocate water among competing demands. In the State of Andhra Pradesh, the government has set up a State level Committee for Integrated Water Management (SCIWAM), which has representatives from all water related sectors (http://www.apwaterreforms.in/downloads/GOs/5.GO.Ms.No.63.PDF) (Accessed June 26 ${ }^{\text {th }}, 2013$ ). SCIWAM considers the demands of various sectors and puts forward its decision to the state government for issue of water allocation orders. Water resources allocation to various sectors is given preference based on the water supply and demand. Nonetheless, there is no proper tool to estimate the demand and allocate the resources optimally between sectors.

In normal hydrological years, water allocation in Andhra Pradesh is basically easy, as the needs of all sectors can be met. Problems arise in years when the rainfall is insufficient or late. Lately, the Indian sub-continent has witnessed several years of drought and changed monsoon patterns, and this increases the challenges of water allocation. In such dry years, negotiations with stakeholders at different levels are required, and it can be a rather challenging process to make decisions that will satisfy all sectors' water needs. The present approach to water allocation in such situations is more influenced by perceived demands and political priorities, and there is, therefore, a need for more scientific tools that may help in optimal allocation of water resources to different sectors.

In this study, an adapted version of the Building Block Methodology (BBM) (Tharme \& King, 1998) was tested out as an alternative approach for water allocation between sectors on the Sri Ram Sagar Project (SRSP) on the Godavari River Basin in Andhra Pradesh, India. The BBM is participatory by nature and involves stakeholders in the process of estimating optimal water allocation regimes. As far as the authors know, the BBM has never been used as a tool for allocating water between sectors with conflicting interests, only as a tool for assessing dynamic flow releases for environmental purposes. The main purpose of this paper is to:

- Assess the water allocation regimes in the Sri Ram Sagar Project (SRSP) under various hydrological conditions (normal year, dry year and under future climate change) and different levels of demand fulfillments.

- Identify possible measures to reduce water consumption in the SRSP, with focus on irrigation.

- Evaluate the adapted BBM-approach as a tool in water allocation between competing sectors.

\section{Description of the Study Area and Future Hydrological Situation}

\subsection{The Sri Ram Sagar Project (SRSP)}

The Sri Ram Sagar Project is a multi-purpose project, located across the Godavari River near Pochampad of Nizamabad District in Andhra Pradesh (Figure 1). The project was cleared in 1946 for utilization of 66 TMC (thousand million cubic-feet) of water from the Godavari River. As a result of an inter-state accord, the allocation was increased from 66 TMC to more than 200 TMC (www.aponline.gov.in; accessed June $26^{\text {th }}, 2013$ ), but later limited to $122 \mathrm{TMC}$ due to capacity constraints. The catchment area upstream of the dam site is 91,751 $\mathrm{km} 2$ and the surface area of the reservoir is $453 \mathrm{~km}^{2}$. The reservoir water irrigates 0.39 million ha of land through three canals (Table 1) and supplies nearby areas with drinking water and water for hydropower generation (installed capacity is $36 \mathrm{MW}$ in four $9 \mathrm{MW}$ units) (ibid.). The water used for hydropower production is later released for irrigation in the Kakatiya Canal (Table 1). $146 \mathrm{~km}$ downstream from SRS dam, the Kakatiya Canal crosses the Manair River and water may also be stored at Lower Manair Dam. A flood flow canal (FFC) may discharge excess water towards the right bank also flowing into Lower Manair Dam when the reservoir level exceeds $1070 \mathrm{ft}$. In addition to water from the reservoir, groundwater is also an important source for irrigation in this region. It is difficult to assess the quantities of irrigation water coming groundwater versus the reservoir, and this might also vary extensively within the SRSP, over the year and from year to year. Use of groundwater might also be limited in some parts of the area due to reasons such as limitations in access to electricity for pumping and the quality of the water. 


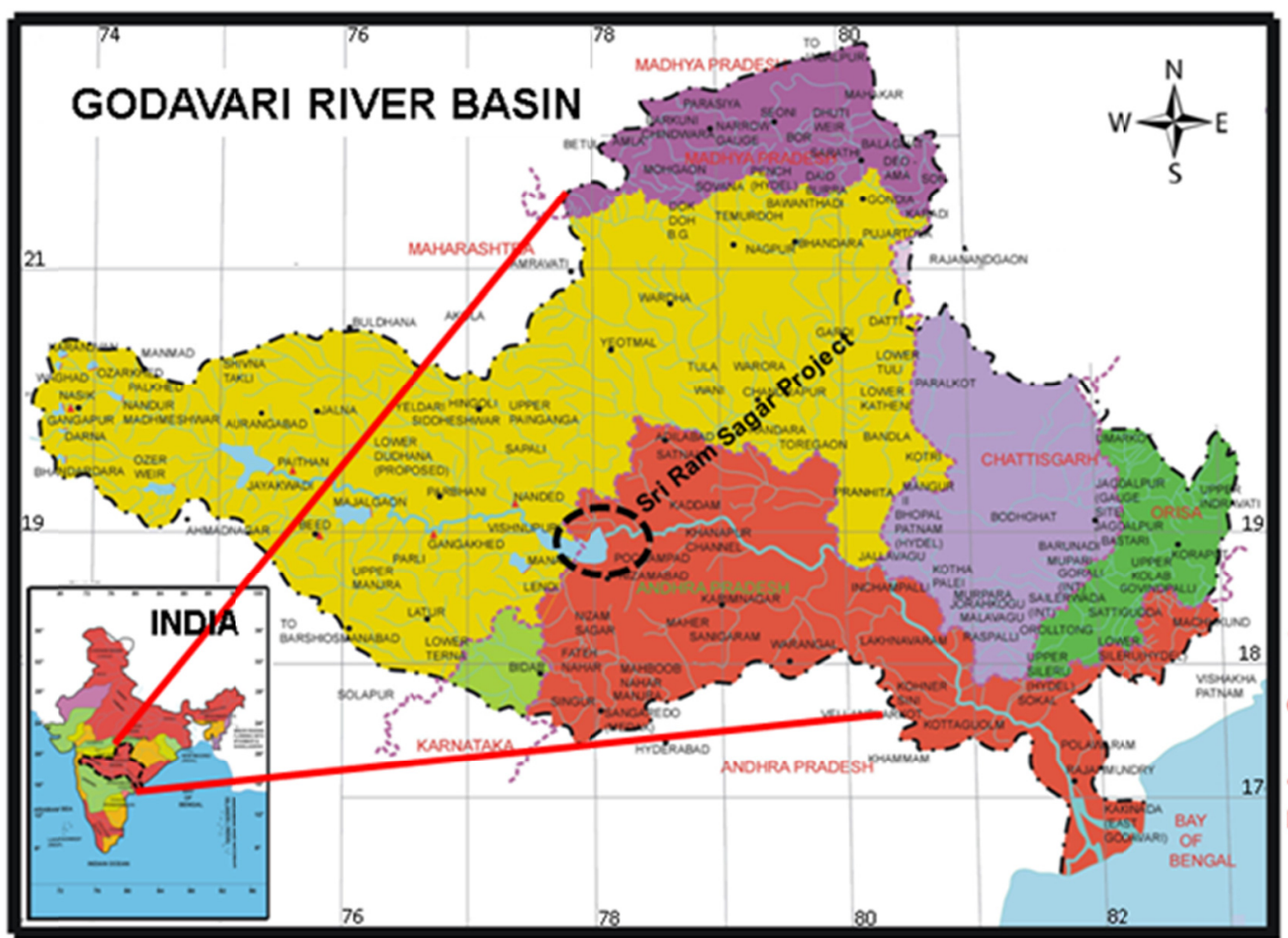

Figure 1. The map shows the location of the Sri Ram Sagar Project (SRSP) within Godavari River Basin in India

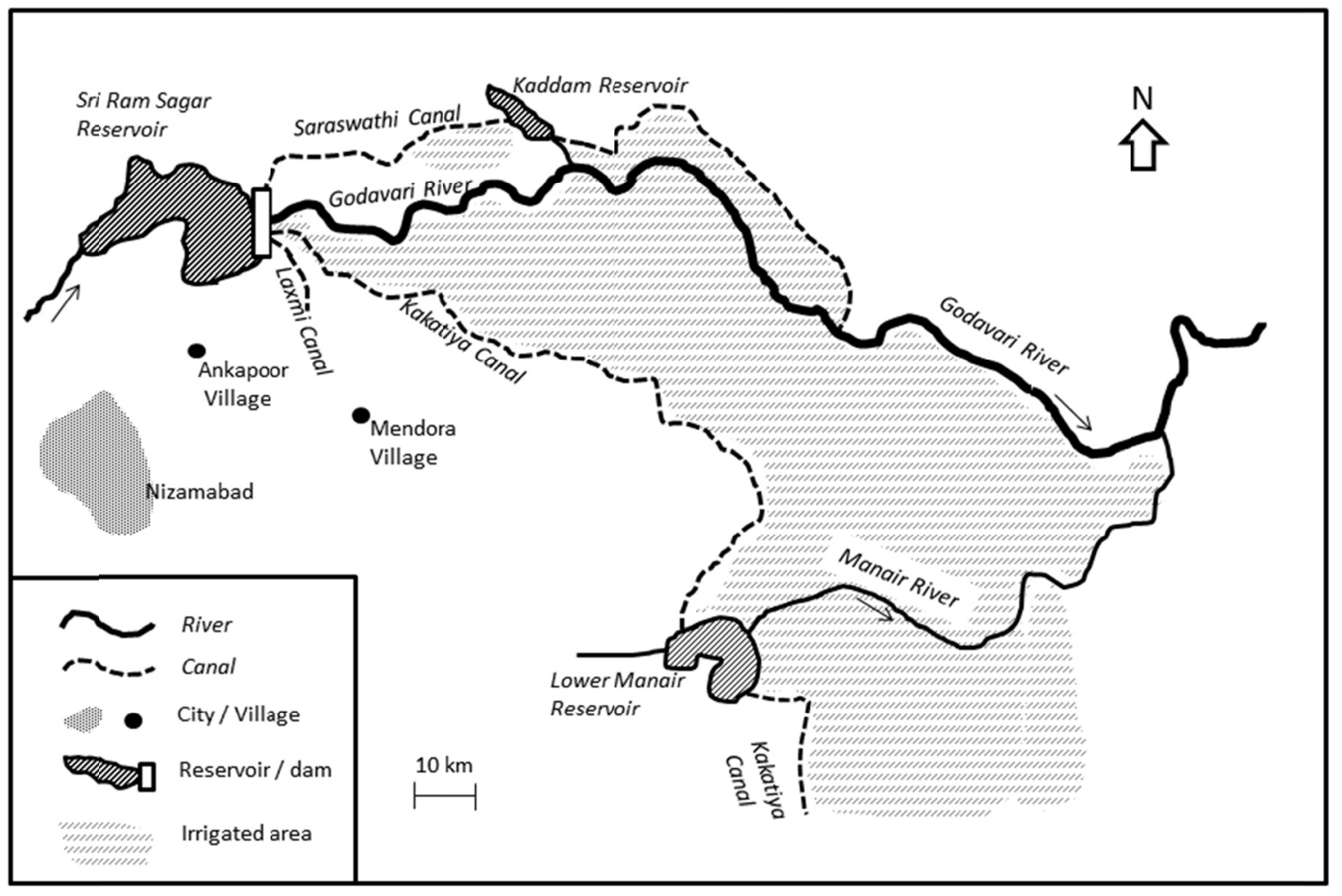

Figure 2. Sri Ram Sagar Project (SRSP) with its canals, reservoirs, dams and irrigated fields 
Table 1. Basic characteristics of canals receiving water from the Sri Ram Sagar Reservoir

\begin{tabular}{cccc}
\hline Canal & $\begin{array}{c}\text { Length } \\
{[\mathrm{km}]}\end{array}$ & $\begin{array}{c}\text { Capacity } \\
{\left[\mathrm{m}^{3} / \mathrm{s}\right]}\end{array}$ & $\begin{array}{c}\text { Linked to hydropower } \\
{[\text { Yes/No] }}\end{array}$ \\
\hline Kakatiya (right bank) & 284 & 274.7 & Yes \\
Saraswathi (left bank) & 47 & 42.8 & No \\
Laxmi (right bank) & 3.5 & 14.1 & No \\
FFC (right bank) & & 623 & Not directly, but may feed lower Manair \\
& & & dam which also has hydropower \\
\hline
\end{tabular}

In addition to irrigation and hydropower, the SRSP also provides drinking water to urban and rural areas along the canal system. The drinking water allocation for rural areas ranges from 55-100 litres per capita per day, whereas for urban areas it is 70-120 litres per capita per day (estimated by the workshop participants). The number of people served by SRSP is approximately 12.6 million in total.

The cropping pattern proposed for SRSP in the early stages was to grow only irrigated dry crops like maize, groundnut, jowar and pulses. However, the cropping pattern has changed over the years into more water demanding crops, and paddy rice, together with maize and groundnut, are now the main crops (SRPS, 2009), in both the wet (Kharif, which covers the months June/July - November) and dry season (Rabi, which covers the months December - March/April). The cropping pattern changes with the variation in rainfall. The mean annual rainfall in the area of SRSP is $900 \mathrm{~mm}$ of which more than 75 per cent is received in the south-west monsoon period. During the 2000's, the driest year was 2004-05, where only 55 per cent of the mean annual rainfall was received and no water was available through canals to the command area (SRSP, 2009).

Water user associations (WUA) for major, medium and minor irrigation units were formed in 1997 through the Andhra Pradesh Farmers Management of Irrigation System (APFMIS) Act. This legislation was the first of its kind in India. The WUAs are responsible for regulation of water and maintenance of the irrigation system in their jurisdiction. While WUAs are the first level institutions of the farmers, the Distributary Committee (DC) and the Project Committees (PC) form the intermediary and apex institutional levels.

In each district there is an Irrigation Advisory Board (IAB). This irrigation board normally conducts meetings in July and October with the District Collector (the highest government official at the district level), the concerned irrigation minister, PC chair persons, DC presidents, WUA presidents and concerned line departments (including representatives from the rural water supply, agriculture, groundwater and fisheries). During the meeting the water allocation is discussed. Basically, drinking water is the first priority of water allocation, followed by irrigation and hydropower. If the water level is below 45 TMC in the SRSP, no water is allocated for irrigation or hydropower. In principle, the allocation is based on a demand-/supply approach, but no in-depth analysis is basically carried out prior to setting the water allocation each year. Hence, an accounting framework and suitable methods to allocate water between the different interests and stakeholders, such as the BBM-approach, is relevant to explore.

Palanisami et al. (2011) constructed a vulnerability index related to water supply for the Godavari River Basin districts of Andhra Pradesh state considering exposure, sensitivity and adaptive capacity. The results illustrate that all the 4 districts (Nizamabad, Adilabad, Karimnagarand Warangal) supplied by the irrigation canals are vulnerable. Considering the level of vulnerability, Adilabad district is falling in the category of highly vulnerable, while Warangal district is vulnerable, Nizamabad and Karimnagar are moderately vulnerable.

\subsection{Predicted Future Climate Change and Implications on the Water Resources}

The study in the SRSP also aimed at covering scenarios for future changes in water availability and water demand. In order to prepare data for the future hydrological situation, affected by climate change, the PRECIS Hadley Centre regional climate model (Jones et al., 2004), with a grid resolution of $0.44^{\circ} \times 0.44^{\circ}$ was used. The Indian RCM PRECIS was configured for a domain extending from about $1.5^{\circ} \mathrm{N}$ to $38^{\circ} \mathrm{N}$ and $56^{\circ} \mathrm{E}$ to $103^{\circ} \mathrm{E}$. The IPCC SRES A1B Scenario (IPCC, 2000) - Q14 Qump (Quantifying Uncertainty in Model Predictions) for the time periods representing the present situation (1961-1990), mid century (2021-2050) and end-century (2071-2100) was made available by IITM (Indian Institute of Tropical Meteorology) Pune. The IPCC SRES A1B scenario is characterized by a very rapid economic growth, a global population that peaks in mid-century and declines thereafter, and rapid introduction of new and more efficient technologies, with the development 
balanced across energy sources. The A1B scenario was selected for use in this study as this was the only scenario for which the RCM PRECIS output was available. Moreover, A1B was considered to closely represent the future conditions.

Based on this scenario analysis, data for different meteorological variables (rainfall, air temperature, solar radiation, relative humidity, wind speed) was extracted for the Godavari Basin and the future situation simulated. These data were used as input to the SWAT hydrological model (Arnold et al., 1998). Potential impacts of climate change on water yield and other hydrologic budget components were quantified by running the model with current and future climate conditions over the Godavari River Basin (Gosain et al., 2011).

Climate change scenarios for the Godavari River Basin show that the annual precipitation is expected to increase and the extreme weather conditions are likely to appear more frequently. Mean annual precipitation increases by about $186 \mathrm{~mm}(14 \%)$ by mid-century and by about $243 \mathrm{~mm}(18 \%)$ by end-century under the A1B scenario. Most of the increases occur in the monsoon period, and there is a slight decline in January and February rainfall towards mid-century under the A1B scenario. Mean monsoon rainfall increases by $148 \mathrm{~mm}$ by mid-century and by $116 \mathrm{~mm}$ by end-century (Figure 3 ). The consequence of this is that climate change might lead to a higher risk of floods and maybe also a higher risk of droughts because of higher temperatures.

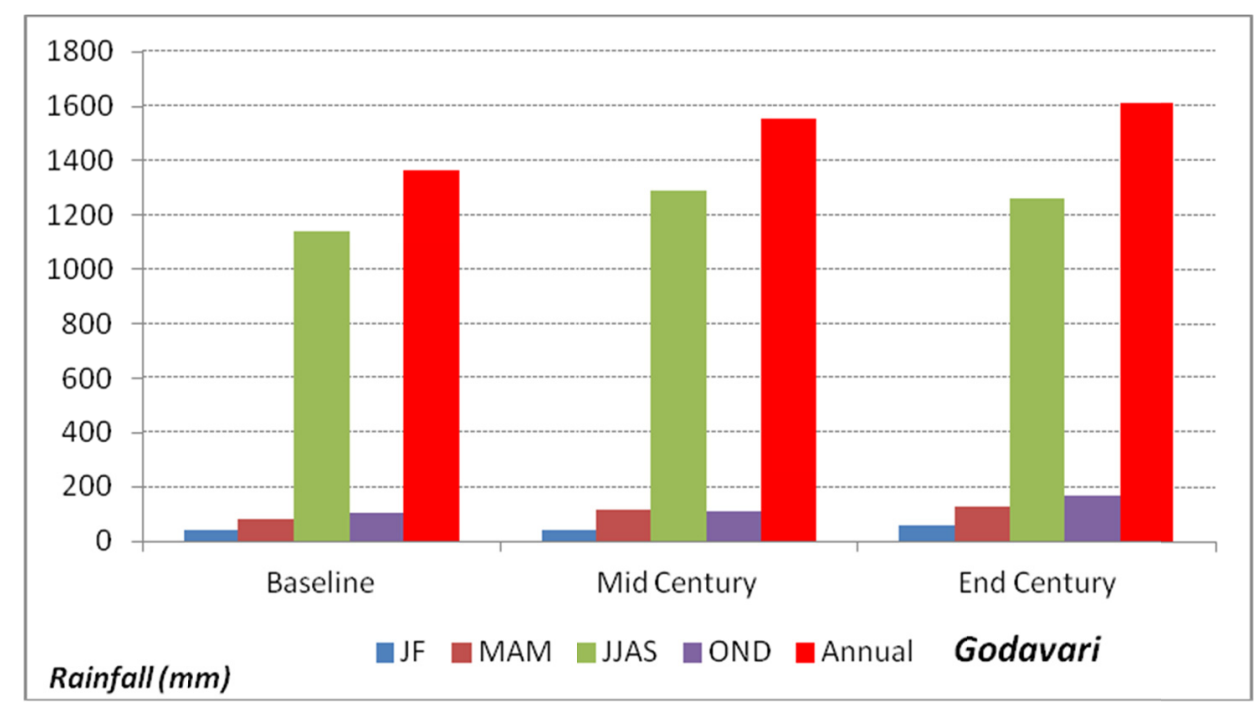

Figure 3. Characteristics of simulated seasonal and annual rainfall over Godavari River Basin for the baseline (1961-1990), mid-century (2021-2050) and end-century (2071-2100) scenarios (Gosain et al., 2011)

Figure 4 shows the spatial variation of the change in the water yield compared to baseline over the Godavari Basin under the end-century scenario. There is an indication of increase in the availability of water in the future. However, this can also imply that there will be more events of flooding. 


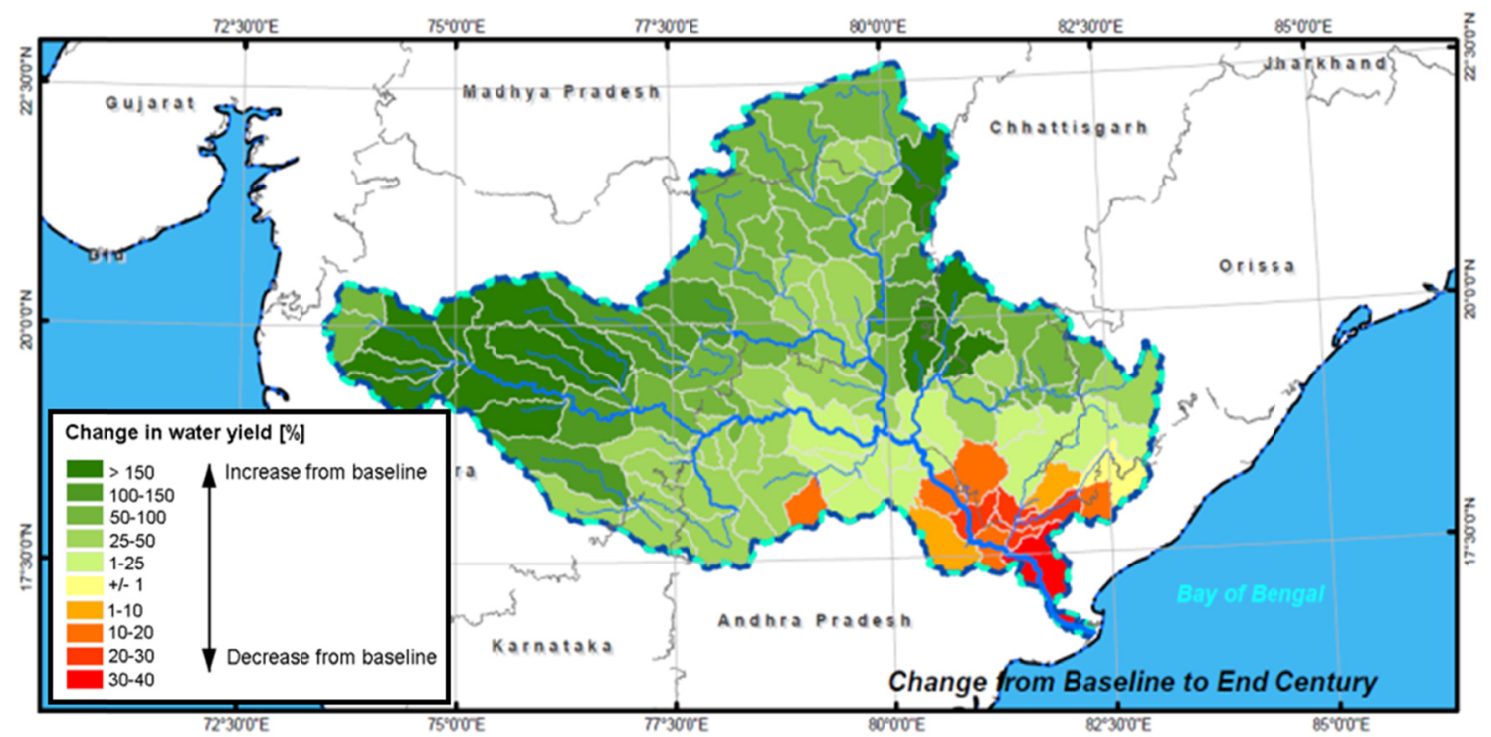

Figure 4. Change (in per cent) in mean annual water yield compared to the baseline for the end-century climate scenarios (IPCC SRES A1B) in the Godavari River Basin (Gosain et al., 2011)

Climate change scenarios for the Godavari River Basin also show that extreme weather conditions are likely to appear more frequently (Gosain et al., 2011), leading to an increased risk of floods and droughts. Under the A1B scenario, rainfall is projected to increase. Mean annual rainfall increases by about $186 \mathrm{~mm}(14 \%)$ by mid-century and by about $243 \mathrm{~mm}(18 \%)$ by end-century under the A1B scenario. Most of the increases occur in the monsoon period. There is a slight decline in January and February rainfall towards the mid-century under the A1B scenario. Mean monsoon rainfall increases by $148 \mathrm{~mm}$ by the mid-century and by $116 \mathrm{~mm}$ by the end-century. The annual amount of rainfall is expected to increase (Gosain et al., 2011). However, the majority of this increase will appear during the wet season, leading to a higher risk of floods, whereas there will be a decrease in rainfall or a marginal increase during the other seasons, meaning a higher risk of droughts because of higher temperatures.

The above predictions indicate that future climate conditions may lead to higher availability of water in SRSP in years where a high reservoir level can be maintained longer into the dry season, due to higher precipitation in combination with an expected decrease of water demand for irrigation. Situations with discharge of excess water may occur more often during the wet season, having positive effect on the areas located downstream of SRSP, unless too much water will result in flooding. On the other hand, future climate conditions may also lead to years with lower availability of water in SRSP, as the risk of droughts will be higher due to high temperatures in the dry season. A severe concern is the reduction of the storage capacity of SRSP due to siltation. Since the construction the capacity has been reduced from original 112 TMC to 91 TMC today. More frequent floods may further accelerate rate of sedimentation in the reservoir.

\section{Applied Methodology}

\subsection{The Adapted Building Block Methodology (BBM)}

The development of the Building Block Method (BBM) originates from South-Africa and dates back to the early 1990s (Tharme \& King, 1998). The approach was developed as a workshop-based method to assess environmental and downstream flows, by including the needs of water flow for different species or ecological functions (Hughes et al., 2006) and taking into consideration the dynamics in the aquatic system, i.e. the variation in flows and needs between seasons and years. The method is considered to be a holistic approach to setting environmental flow as classified by Halleraker and Harby (2006). Alfredsen et al. (2012) reports the application of the BBM concept in a demonstration case in a Norwegian river regulated for hydropower production, where the flow needs for the various life-stages of salmonids are described in detail. Bakken et al. (2012) provides a more systematic overview of cases in Norway where a full or elements of a BBM-methodology has been applied for setting environmental flows in regulated rivers in Norway. 
The basic data/information on water demands for the application of BBM can come from various sources, ranging from detailed and comprehensive model simulations to rough estimates set by experts ('expert judgements'). By bringing together all the experts and stakeholders representing specific water needs, optimum flow conditions are set in a process that is supposed to end in consensus. The typical way of using the BBM-approach is to invite a number of experts, covering different user interests and sciences related to water needs, species and their ecological functions, to set the environmental flow conditions (King, 2000). The organizers of the workshop should provide all relevant data. The water flow requirements are defined individually for all essential components and functions on a monthly basis, also taking into concern the uncertainty in the requirements.

The application of the Building Block Methodology to the Sri Ram Sagar Project widens up the scope from setting the environmental flow, as it includes interests and water requirements from other sectors and groups, including secure drinking water supply, industrial water needs, irrigation and water for electricity production.

The concept as such is, however, similar to setting requirements for environmental flow, as the water demands for the various sectors should be defined on monthly basis, covering also the demands during hydrological wet and dry years. The Building Block Methodology has also been successfully applied in this way to Lake Vansjø in Norway (Skarbøvik et al., 2011). In SRSP, the BBM was not known to the stakeholders in the water sector. In recent years, farmers, represented by the Water User Associations constituted under the Participatory Irrigation Management policy in some states like Andhra Pradesh, are being encouraged to take part in decision making. Hence, the application of the BBM to the Sri Ram Sagar Project is the first known case of BBM in India.

\subsection{The Framework}

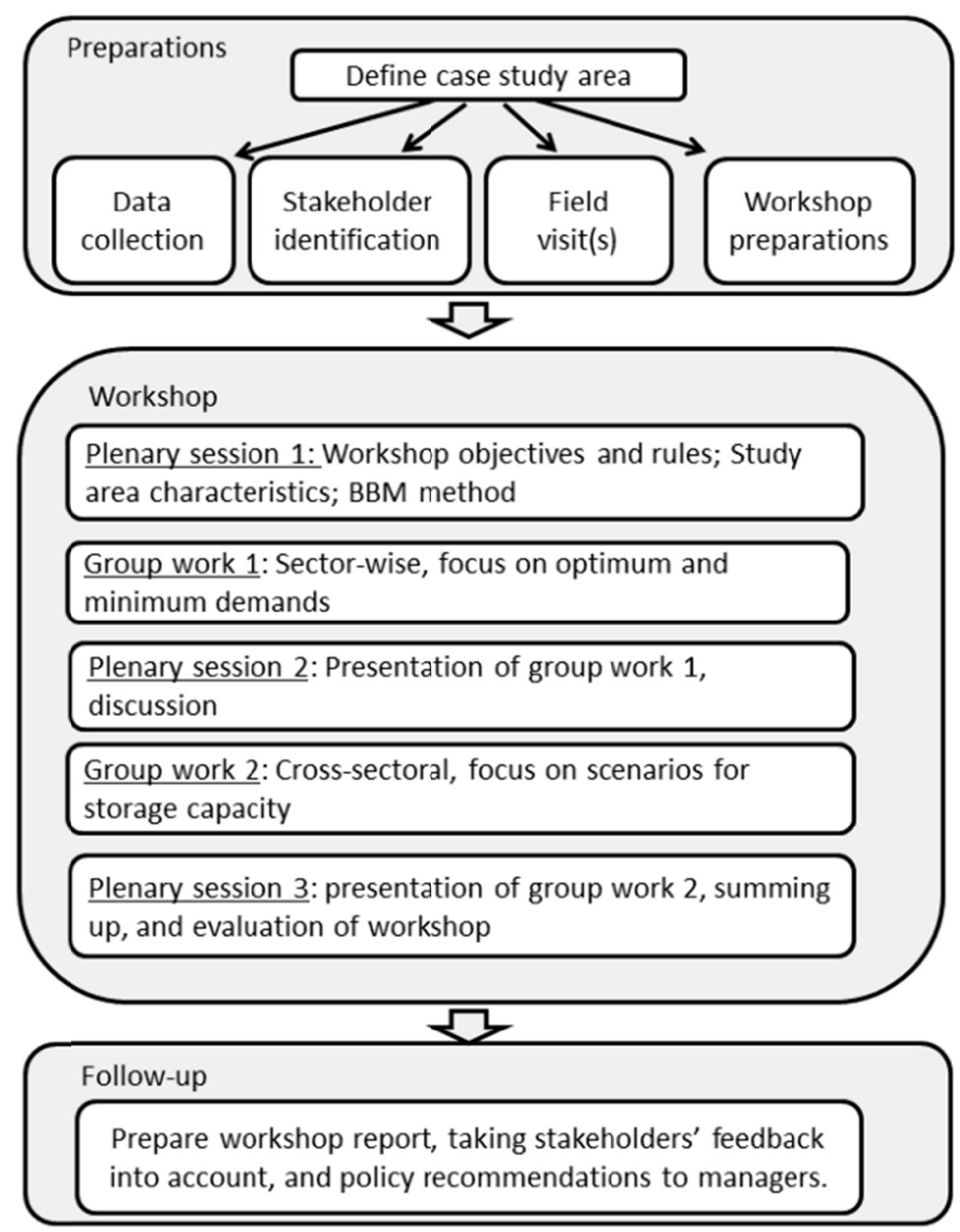

Figure 5. Schematic view of the BBM-process as it was performed in this study. See text for more explanations 
The framework for the BBM is shown in Figure 5. After defining the case study area as the Sri Ram Sagar Reservoir and its downstream areas, reaching as far as the next reservoir, the team collected relevant data and information, including stakeholder identification. This was done in co-operation with local and regional experts.

An important part of the BBM method is that the scientists visit the field area prior to the workshop. In addition to visiting the Sri Ram Sagar dam and reservoir itself, including meetings with dam operators and hydropower personnel, the project team also visited two local villages in order to obtain information on the communities' experiences on water management issues. The field visit enhanced the insight of historical aspects (memories on how the community has coped earlier when faced with floods or droughts), economic aspects (income, insurances, marked situation), social aspects (coping strategies, concerns regarding the governance of the water resources), knowledge aspects (technical skills, knowledge about alternative cropping patterns, knowledge about how to influence the water management) and how the communities regard the future (climate change challenges, technological innovation concerning cropping, irrigation, water storage, etc.).

Next, a one day workshop was organised at the Irrigation \& Command Area Development office in Hyderabad on September 7th, 2011. About 20 stakeholders from relevant sectors with stakes in the SRSP participated. The participants covered the sectors drinking water, irrigation and hydropower from both state governmental and regional levels. More specifically, the following organizations/interest groups were present:

- Department of Animal husbandry, Nizamabad district authorities

- Department of Groundwater, Nizamabad district

- Rural water supply department, Nizamabad

- APTRANSCO Nizamabad (State Hydropower Corporation)

- Department of Irrigation and Command Area Development, Government of Andhra Pradesh

- Department of Agriculture, Government of Andhra Pradesh

- Water and Land Irrigation Management and Training Institute, Hyderabad

- International Water Management Institute

- Nizam Sagar Project

The workshop was divided into plenary and group work sessions. In the first plenary session general information about the purpose of the workshop was given. In addition, the expectations of the workshop participants' were explored, a brief introduction to the BBM was given, and workshop guidelines and rules discussed. When applying the concept in the workshop, a set of rules was clarified for the participants;

- All participants should freely express their genuine water demand;

- All participants should accept that persons from other sectors express their needs, and the water demands should basically not be disputed;

- All participants should express their demands and desired withdrawal in thousand millions of cubic feet (stored water) per month (TMC/month).

The group work session was split into two parts, where the participants first discussed the water demands in groups with members only from their own sector (e.g., hydropower, drinking water, or irrigation). After a plenary session where group work 1 was presented, the groups were reorganized to include participants from all sectors, and the water demands were then discussed again. In this second group work, scenarios for future water use were also brought into the discussions. Towards the end of the workshop, the BBM results were presented and discussed in plenary and the workshop was evaluated.

The final step of the process comprised the writing of a workshop report, as well as policy and technical briefs that were distributed to stakeholders for comments, before dissemination to managers.

\section{Results from the Application of BBM}

\subsection{Community Perspectives on Water Allocation}

A village meeting was organised in each of the two villages Mendora and Ankapoor (the latter village has formed a cooperative society named Ankapoor Cooperative Society). In the Mendora village about 30 per cent of the cultivated land is used for paddy, whereas 70 per cent of the cultivated land is used for dry crops. In the wet season, more land is used for paddy cultivation, but the farmers are concerned about the fact that it is difficult to convert dry land into paddy fields. The main reason for growing paddy is that paddy is covered by the Price Support Policy of the Government through a Minimum Support Price (MSP). The knowledge about less water 
consuming crops is limited, and proper training is seen as a necessity in order to reduce the water consumption to match the available water resources, especially in dry years. Among the farmers, the allocation of water to the individual fields is generally considered to be a problem due to a lack of proper maintenance of the canals, a lack of ponds and tanks for storage of water, a lack of a functional mechanical systems to release water according to the different needs at different time, and a lack of sufficient supply of electricity during daytime in order to pump water.

Whereas the Mendora village faced several challenges concerning the current and future water management, while the other village, the Ankapoor Cooperative Society, represented quite a different story. It covers an area of 2000 hectares and the cooperative focuses on cultivation and processing of seeds for cattle fodder which is used both locally as well as sold to other areas. The success was assumed by the villagers to be the access to a market willing to pay a profitable price. Today, the Ankapoor Cooperative Society grows crops that demand only a limited amount of water, including turmeric, sorghum, chili, tomato, coriander, maize and bajra (pearl millet). Since paddy is not grown, the need for water for irrigation is limited compared to the situation in the Mendora village. In order to be able to cultivate throughout the entire year, only a limited part of the tilled land is used for cultivation at a time. Despite the success, the cooperative today faces a challenge with respect to the future need for labour, since the younger generation has moved away from the village to go to schools, universities and jobs elsewhere.

The two villages further have a common challenge regarding the gendered division of labour (Massey, 1994) where women are central in the management of water for irrigation needs, but where they only have limited access to forums where new irrigation methods are discussed, as well as to forums where proper training is given (irrigation methods, knowledge about crops and cropping in order to save water, etc.). Since land is mostly in the name of the male, women are excluded in most aspects of discussion related to irrigation.

The information gained by the field visit to the two local villages showed that there is a great potential for reducing the water consumption in the agricultural sector in this region, as these two villages represent two different stories where the village with reduced water consumption seems to have the better economical outcome despite less use of a limited resource. This is probably due to the fact that there are better water management practices coupled with better institutional arrangements in place in the Ankapoor Cooperative Society (technically, organisational, and knowledge-wise), and a better understanding of the market for trading the produce. Such information from villages is essential for making water allocations, but also provides a basis for future water management.

\subsection{Water Allocation Regimes During Present and Future Conditions}

During the sector-wise group work at the BBM workshop the optimum and minimum demands for irrigation, drinking water and hydropower were discussed and calculated for the present and future, defined as in 10 years' time. It was decided to use a relatively short time horizon for the future water demand scenario in order to ensure that the participants could easily identify with the scenario and provide realistic water demand estimates. The use of the term 'optimum' refers in this context to the situation when the water demands of all sectors are fully met. In addition, water allocated to environmental flow was introduced by experts in the project team, mainly for illustrative purposes as there presently are no defined requirements for environmental flow in the Godavari River. Figure 6 shows the optimum water demand for the present and future. The amount of irrigation water required from the Sri Ram Sagar Reservoir was calculated taking into consideration cultivation of wet and dry crops, respectively, minus the proportion of irrigation water covered by the use of groundwater. The minimum demand was obtained by reducing the optimum demand by 20 per cent for all months, based on expert judgements from the workshop participants. This is a very rough factor as the use of groundwater versus reservoir water a big spatial variation within the area and might also vary from year to year. In the future, water use for irrigation supplied by the reservoir was assumed to decline by 5-10 per cent due to factors such as a change in crop types, increased use of groundwater, improved management and efficiency in the irrigation system and technology. The drinking water demand was calculated based on a fixed rate of consumption per capita, and it was differentiated between rural and urban population. It was decided that the demand should be limited to human beings; hence livestock was not accounted for. Since influences like population growth, urbanisation and losses in the pipeline system were considered; it was assumed that drinking water consumption would increase in the coming years. The water demand for hydropower was based on the present maximum and minimum power production, respectively. The demand is unlikely to change because there are no plans for extending the capacity of the operation of the hydropower station. As noted earlier, the demand for hydropower also accounts for irrigation, as the water from the turbines discharges into one of the irrigation canals (Kakatiya). This means that there is no 
additional hydropower demand if the demand for irrigation is equal to or greater than the demand for hydropower.

According to these calculations and assumptions, the total water demand is expected to decrease by 1 to $10 \mathrm{TMC}$ in the period of August to December within the next 10 years, as a result of reduced demand for irrigation. In the remaining months of the year, the effect of larger demand for drinking water is negligible with an overall increase in water demand of less than $0.1 \mathrm{TMC}$.
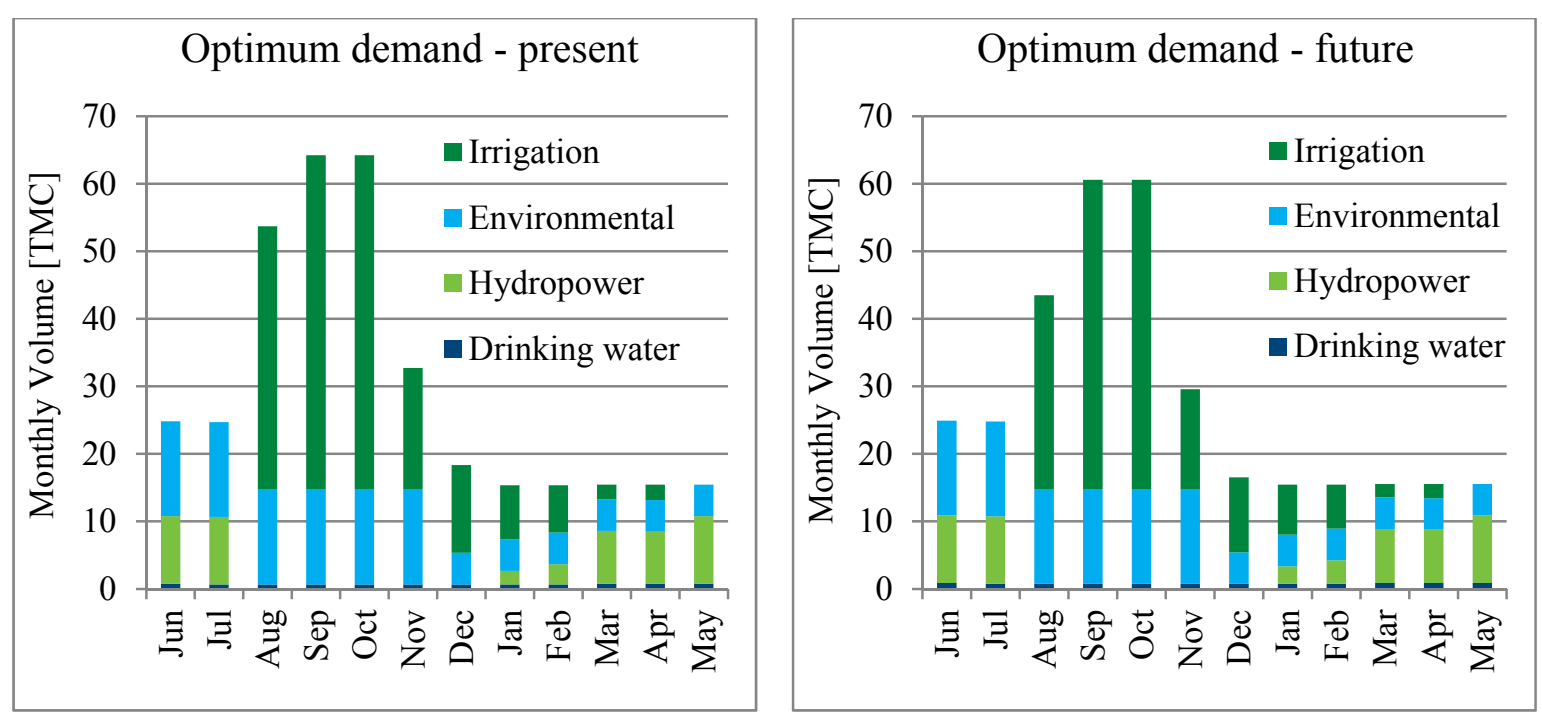

Figure 6. Required monthly volumes of water from the Sri Ram Sagar Reservoir. The optimum demands are given sector-wise for the present (left) and as expected in 10 years time (right)

Figure 7 shows scenarios for the water volumes stored in the Sri Ram Sagar Reservoir. The scenarios are based on historical data from the reservoir and the demands identified in the group work of the workshop, and illustrate potential water allocation problems, as demonstrated at the workshop. The purpose of this figure was to use the scenarios as a basis for the workshop discussions on alternative water allocation strategies, and measures to balance demand and availability of water. It should be noticed that the demands include a proposed environmental flow, which was added by experts in the project team. The monthly storage in the reservoir for present conditions was shown for the cases that the optimum and minimum demands are withdrawn from the reservoir, compared to the actual storage during a normal and a dry year (Figure 7). During a normal year, water shortage may occur in the beginning of the wet season if the inflow has not been large enough to fill the reservoir and the optimum demand is withdrawn. In this case, water shortage is also indicated for the second half of the dry season (March to May). If the minimum amount of water is abstracted, the curve is similar to the present storage available in a normal year, but there is more water stored in the reservoir in the second half of the dry season. For a dry year, it is unlikely that higher amounts of water than the minimum demand are abstracted. For this scenario, water shortage becomes obvious, as there is too little water in the reservoir from the beginning. This situation reflects the problems with water shortage in dry years as described by the farmers during the field visits and the workshop participants. 

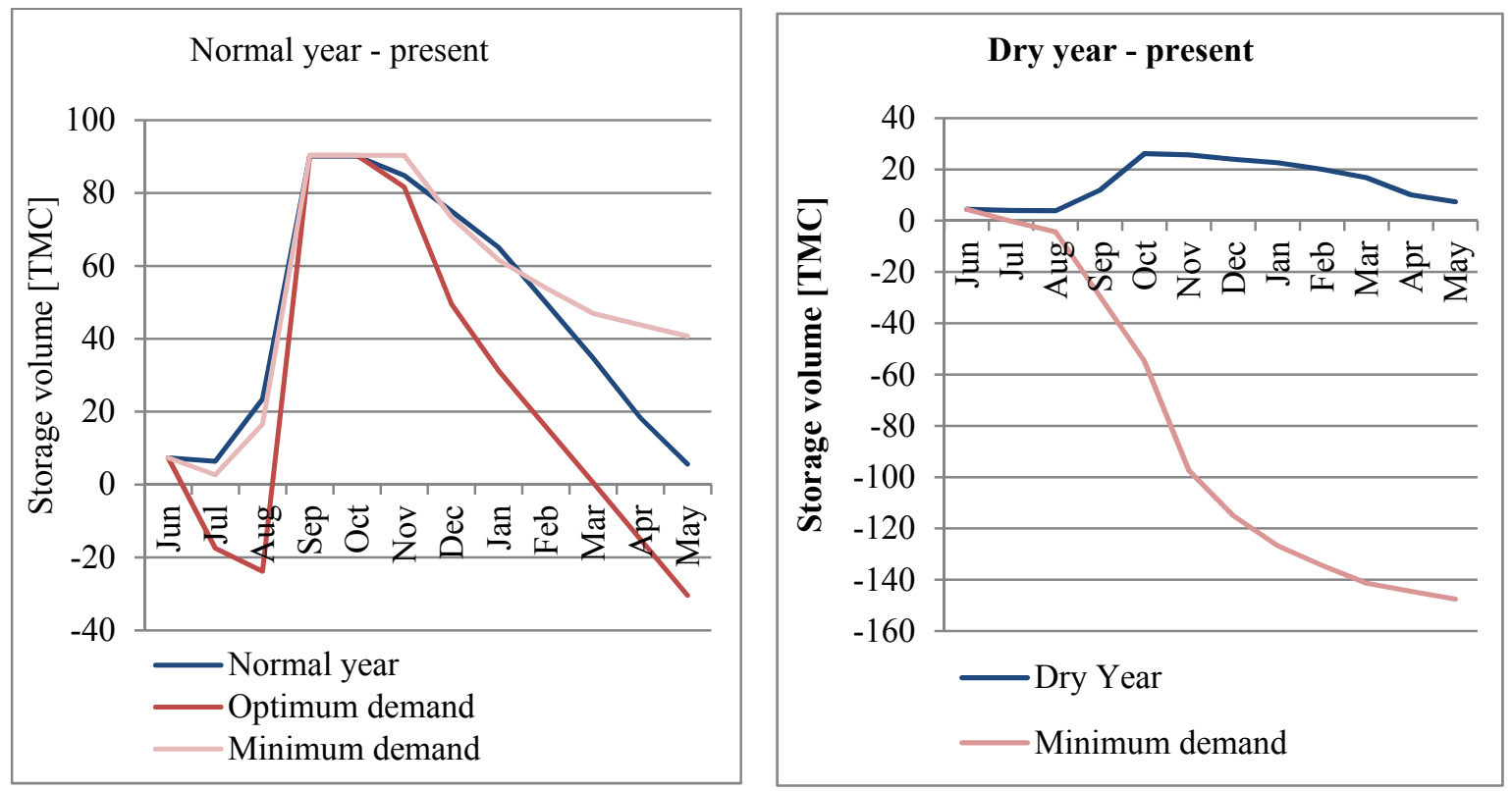

Figure 7. Scenarios for the water volume stored in the Sri Ram Sagar Reservoir for a normal year (left) and a dry year (right) at present conditions, illustrating potential water allocation problems as demonstrated during the workshop. The blue line shows the available water in the reservoir during a normal year (left) and a dry year (right), based on historical data from the period 1983 to 2010. The two red lines show the amount of stored water if the minimum (light red) and optimum (dark red) demand is withdrawn from the reservoir, including water for drinking, irrigation, hydropower and environmental flow. Optimum demand is not relevant in dry years and therefore not shown in the right-hand chart. Values below 0 are only for illustration and could not happen in reality

Based on the climate change scenarios and the above analysis of water demand in dry and normal years, it is possible to assess, albeit informally, if the conflicts over available water will intensify in the future. The climate change scenarios predict that the overall inflow of water to SRSP is expected to increase in the wet period at the mid- and end-century, assuming that all other factors do not change (e.g. no land use changes). At the same time, however, the storage capacity of the SRSP is expected to be reduced due to siltation. Furthermore, the scenarios for climate change point in the direction that also the risk of droughts will increase.

Despite the difficulties in assessing the water availability in SRSP in the future, it seems that climate change itself will not make the water stress more severe. However, the fact that the storage capacity will gradually decrease due to siltation of the reservoir and the possibility for more droughts, will in the longer term lead to a need for additional capacity to store water from the wet to the dry season in order to reduce the vulnerability for water stress.

\subsection{Formal Evaluation of the BBM-Workshop}

A one-page evaluation form was distributed to the participants at the end of the one-day workshop (see Sauterleute et al., 2012 for details). The form was filled in by 15 respondents, and the participants' experiences from using the BBM were overall positive. Most respondents expressed that the method was easy to use, that it ensured that all views were heard, and that they would consider introducing the method elsewhere. Two participants, who were invited to express their views more informally at the end of the workshop, characterized the BBM as a tool that was easy to use and, as one of them commented; whereas simple issues are often made complex, the BBM method managed the unusual task to simplify complex issues.

In terms of future improvements of the process, the participants suggested that the workshop process would be improved if the time-frame was extended. Two days of field visits and meetings should be followed by a two-day long workshop. More time should also be allocated for the preparations, including detailed information and clear instructions to the participants on the workshop process, the group work tasks and the expectations on their contribution. 


\section{Discussion}

\subsection{Uncertainty in the Hydrology and Demand Estimates}

This exercise on using the BBM method to allocate water to different sectors during various hydrological scenarios and different levels of demand fulfilment has revealed a number of interesting findings. The process also identified uncertainties in the available data and the given assumptions. The scenarios for the monthly amounts of water stored in the Sri Ram Sagar Reservoir, which were presented at the workshop, are subject to uncertainties simply because of the uncertainty of the data they were based on. The optimum and minimum demands were determined during the workshop group work, but depend on a number of assumptions, such as the proportion of groundwater irrigation, the possible increase in irrigation efficiency, the number of people that receive drinking water supply from the reservoir, etc. Nevertheless, the assumptions were assumed to be realistic, as indicated by the scenario for a normal year at present conditions.

Another element adding uncertainty to the scenarios is the sensitivity to the initial amount of water stored in the reservoir. During a dry year, when the reservoir is not filled to its maximum during the wet season, the risk of water shortage increases with decreasing amount of water stored in the beginning of the wet season. The initial volume in the presented scenarios for both wet and dry years is typically only occurring during dry years. Furthermore, in the calculations of the available water stored in the reservoir, evaporation, leakage and loss of storage capacity due to siltation were not considered. However, the data accuracy was sufficient for illustrating potential water allocation problems in the workshop, and for testing the BBM methodology.

Environmental flows have not been considered in the SRSP, and it is deemed unrealistic to allocate water to environmental demands if drinking water supply and irrigation demands are not covered. Nevertheless, it was considered useful to include the demand for environmental flows in the workshop in order to make the participants aware that such releases may serve purposes not yet fully acknowledged in the region, including aquatic and terrestrial ecology, as well as fish production.

\subsection{Uncertainty in the Climate Change Predictions}

The scenarios for the future water availability are uncertain for several reasons, including the fact that regions strongly affected by monsoon rain are difficult to model in the GCMs (Global Circulation Models) (Gosain et al., 2011), as well as difficulties in selecting the most likely emission scenario, and in downscaling of the GCM-results to Godavari River Basin and the Sri Ram Sagar Reservoir. The annual water yield is expected to increase, but most of this increase is expected to occur during the wet season, leading to a higher risk of floods. Due to higher temperatures and decreases and/or marginal increases in precipitation (no clear signal in the modelling results) during the dry season, the risk of droughts will be higher. At the same time, an expected increase in the siltation of the reservoir will reduce the storage capacity and may lead to lower availability of water in SRSP. Furthermore, the development of the area upstream the Sri Ram Sagar Reservoir in the Godavari River Basin may have a large impact on available water downstream. The upstream water use may also change depending on factors like land use changes, population growth, degree of urbanisation, agricultural practice and climate change. The combined effect of these factors on the annual water availability is difficult to assess. There is also a certain mismatch between the timing of the water demand estimates (10 years time from now) and the climate change predictions closest in time (mid-century). Consequently, there is a considerable uncertainty in the assessment of the future water availability in SRSP.

It should be mentioned that conflicts between upstream and downstream water use were not properly handled in this study as the focus was exclusively on stakeholders extracting water directly from the Sri Ram Sagar Reservoir. Acting as a tool for integrated river basin management, the water users upstream of the reservoir should be involved as well as the stakeholders downstream. Exclusively focusing on the water needs of those withdrawing water directly from Sri Ram Sagar Reservoir would lead to local optimisation of water use and possible conflicts with upstream stakeholders.

\subsection{Measures for the Reduction of the Water Demand}

A number of solutions were discussed during the workshop in order to close the gap between the available water (normal and dry years) and the present and future water demands. As the volumes of water allocated for irrigation purposes are so large compared to the other sectors, it seemed reasonable to focus measures in this sector. According to the workshop participants, water-saving in the irrigation sector is probably also the most cost-efficient way to reduce the water consumption. The measures in this sector mainly include improved water management practices, taking into account both organisational and technical measures. Examples are changes of the crop pattern, shift of irrigation technology, and improved use of so-called village tank storage (i.e. smaller 
storage basins within the catchment). Technical solutions for drip irrigation and other modern irrigation methods are also known to reduce the need for water. Furthermore, according to the farmers living in the villages close to the Sri Ram Sagar dam, the control and monitoring system for allocating water is not always working or even not in place. In some cases, the villages close to the dam receive too much water while irrigated land further away does not receive enough water. There is always a possibility of increasing the efficiency of the irrigation system and then reduce the need for water if control and monitoring system can be improved. During the field visit to two of the villages we could observe that farm pond as a water saving measure was common in the study area. In one of the villages farm ponds were observed on several farms, and these ponds meet water requirements during dry spells within the monsoon season.

For hydropower there are no feasible measures in the SRSP-case as the hydropower production is directly connected to one of the irrigation canals. It could be possible to develop a small-scale power plant on the left bank of the reservoir in combination with water release to the Saraswathi canal, but the potential energy production is not very high. However, as both the FCC and Kakatyia canals may divert water into Lower Manair Dam, they may feed the much larger power plant of $600 \mathrm{MW}$ at Lower Manair Dam in periods with excess water.

\subsection{Social, Institutional and Political Aspects of Applying the BBM}

Information gained during the meetings in the two visited villages as well as in related discussions in the workshop, indicated that allocations of water resources are made complicated due to a range of factors that go beyond the specific interests of a group or an area. First of all, the water priority is decided at the state level, and there is no sufficient system to handle typical upstream-downstream water conflicts when the rivers are trans-boundary. Secondly, sectorial political concerns make it difficult to have a common water priority. Despite efforts made to inform the population on the need to economize their water use, the health authorities also encourage people to consume more water in order to improve the sanitary conditions in the country. Thirdly, it is estimated that the demand for drinking water will increase in the future due to population growth and urbanisation (GOI, 2011). A discussion of how to share limited resources was therefore seen as important, even though some of the representatives argued that such a planning instrument was already in place. Fourthly, and as shown in the case of the Mendora village, there is a need for both improved technical training when it comes to the use of new irrigation methods, as well as a need for knowledge among the farmers about alternative crops that demand less water. And finally, local participation in water management decision boards was seen as important in order to improve the water allocation system. Although representatives from the Water User Associations are represented in the management at the State level today, it is expected that it will take some time to make the system well-functioning.

One of the basic pillars of the BBM-approach is that the method should end in consensus. It is clear that such a goal is not always possible to achieve, and more time will be needed in a real management case than was allocated in our demonstration case. It is not difficult to foresee scenarios, especially when water allocation in dry years is negotiated, which can hardly end in a situation where all involved parties are satisfied with the outcome. Applying the BBM and discussing alternative water allocation prior to these, more extreme situations might, however, lower the tension in a future conflict. The evaluation of the workshop showed, however, that a majority of the respondents were positive to using the BBM for water allocation purposes.

Finally, it should be commented that the management of water resources involves more than environmental, technical, economical and geographical issues. By applying the BBM in this case study, it could not be ruled out that management of natural resources also involves an element of power concerning control, rights and claims which has to be taken into consideration when conducting workshops (Karlsson, 2011). A challenge in this case study was, however, that the priority of water allocation seemed to have been more or less given, since the state policy basically decides the priority (first drinking water, secondly irrigation and then other needs). Still, the discussions in the visited villages, as well as in the workshop, showed the potential and need for broad involvement across sectors and levels of governance, in order to find better solutions for future allocations of water.

\section{Conclusions}

In this study, a modified version of the Building Block Methodology (BBM) was demonstrated for allocation of waters between different sectors. The methodology is a workshop-based tool for assessing water allocation between competing sectors that requires extensive stakeholder involvement. The tool was demonstrated for allocation of water in the Sri Ram Sagar water reservoir in the Godavari Basin, Andhra Pradesh, India. The main 
conclusion is that BBM proved to be a practical and useful tool in water allocation between sector interests. Other conclusions can be summarised as follows:

- The framework provided by the BBM ensured an atmosphere where all levels of management and stakeholders were allowed to express their views freely.

- However, the workshop was strictly theoretical, as the priority of the water allocation between sector interests are very clearly given by state policies. If the workshop had been operational aiming at really distributing future water consumption, it is not unlikely that we would have experienced a different atmosphere where also hierarchy and position among participants could have been an important factor.

- Priorities for water allocations are already given by state-policies in India. The introduction of BBM has nevertheless a potential for increasing the understanding of the water needs between sectors, making the processes of setting allocation regimes more transparent and stimulating the dialogue.

- The water demands in this case-study region are not always met for each sector under the present situation. This is in particular the situation in dry years. Future water demands for irrigation is expected to decrease due to more efficient technology and improved management, and this would more than balance the expected increased demand for drinking water. Coupled with the climate change scenarios it seems likely that the regions served by SRSP will not experience more severe water stress in the future. The expected reduction in storage capabilities of SRSP due to siltation will, however, in the longer run lead to a need for additional capacity to store water from the wet to the dry season.

Furthermore, it is worthwhile noting from our study:

- There are great uncertainties related to these scenarios due to uncertainties in the GCMs (Global Climate Change Models).

- The hydropower production from SRSP follows the release of irrigation water, as withdrawal of water for hydropower is directly connected to the Kakatiya irrigation canal.

- Water allocation for environmental flows downstream the dam was introduced by the project group mainly for illustrative purposes as there presently are no defined requirements for environmental flow in the Godavari River.

- Our application of BBM in SPRP did not take into account potential upstream/downstream conflicts. This is a clear point for improvement for coming applications of BBM.

The participants at the BBM workshop represented stakeholders within most of the relevant sectors related to the Sri Ram Sagar Reservoir. They were in general positive to apply the BBM to water allocation challenges in the SRSP, and would also support the application to other and similar cases in India. This, in turn, indicates that the BBM approach presented in this paper can be useful also in other areas with competing water interests.

\section{References}

Alfredsen, K., Linnansaari, T., Harby, A., \& Ugedal, O. (2012). Development of an inflow-controlled environmental flow regime for a Norwegian river. River Res. Applic. 28, 731-739. http://dx.doi.org/10.1002/rra.1550

AP Online. $\quad$ Retrieved June 26, from http://www.aponline.gov.in/apportal/departments/departments.asp?dep=20\&org=256\&category=about

Arnold, J. G., Srinivasan, R., Muttiah, S., \& Williams, J. R. (1998). Large-area hydrologic modeling and assessment: Part I. Model development. J. American Water Res. Assoc., 34(1), 73-89. http://dx.doi.org/ 10.1111/j.1752-1688.1998.tb05961.x

Bakken, T. H., Zinke, P., Melcher, A., Sundt, H., Vehanen, T., Jorde, K., \& Acreman, M. (2012). Setting environmental flows in regulated rivers. SINTEF report Serial No. TR A7246. ISBN 978-82-594-3529-3.

Chitale, M. A. (2005). Indian Irrigation Development in Prospect and Retrospect. Institute of Engineers, 85, 221-222.

Government of India (GOI). (2010). Ministry of Water Resources, Government of India. Retrived June 26, 2013, from http://mowr.gov.in/writereaddata/mainlinkFile/File621.pdf

Government of India (GOI). (2011). Ministry of Home Affairs. Office Registrar General \& Census Commissioner, India. Retrived June 26, 2013, from http://censusindia.gov.in/2011-prov-results/indiaatglance.html 
Gosain, A. K., Sandhya, R., \& Debajit, B. (2006). Climate change impact assessment on hydrology of Indian river basins. Current Science, 90(3), 346-353.

Gosain, A. K., Sandhya, R., \& Anamika, A. (2011). Climate change impact assessment of Water Resources of India. Current Science, 101(3), 356-371.

Halleraker, J., \& Harby, A. (2006). Internasjonale metoder for å bestemme miljøbasert vannføring - hvilke egner seg best for norske forhold? Miljøbasert vannføring, rapport nr. 9. Norges vassdrags- og energidirektorat (in Norwegian).

Hughes, D. A., O'Keeffe, J., \& King, J. (1997). Development of a reservoir release operating rule model to simulate demands for instream flow requirements and water resources. IAHS Publication, 240, 321-329.

IPCC. (2000). Special Report on Emission Scenarios. In N. Nakicenovic, \& R. Swart (Eds., p.570), Cambridge University Press.

IWMI. (2002). World irrigation and world water statistics 2002 with a guide to data sources. Colombo, Sri Lanka: International Water Management Institute.

Jones, R. G., Noguer, M., Hassell, D. C., Hudson, D., Wilson, S. S., Jenkins, G. J., \& Mitchell, J. F. B. (2004). Generating high resolution climate change scenarios using PRECIS (p. 40). Exeter, UK: Met Office Hadley Centre.

Kakumanu, K. R. (2009). Economic analysis and management of irrigation systems under subsidized electricity regime in the semi-arid region of Andhra Pradesh, India. Margraf Publishers, 99.

Karlsson, B. K. (2011). Unruly Hills. A political Ecology of India's Northeast. New York: Berghahn Books.

King, J. (2000). Overview of the building block methodology. In King, Tharme \& deVilliers (Eds.) Environmental flow assessment for rivers: Manual for the Building Block Methodology. Freshwater research unit, University of Cape Town, World Commission on Dams Report no. 131/00.

King, J. M., Tharme, R. E., \& de Villiers, M. S. (2008). Environmental flow assessments for rivers: manual for the Building Block Methodology. Water Research Commission. Report No. TT 354/08.

Massey, D. (1994). Space, Place and Gender. Cambridge: Polity Press.

OJEC. (2000). Directive 2000/60/EC of the European Parliament and of the Council of 23 October 2000 establishing a framework for Community action in the field of water policy. Official Journal of the European Communities L 327/1.

Palanisami, K., Ranganathan, C. R., \& Kakumanu, K. R. (2011). Vulnerability assessment and climate change impact Godavari river basin. ITP draft report. IWMI, Hyderabad.

Sauterleute, J., Skarbøvik, E., Bakken, T. H., Egeland, H., Harby, A., Stålnacke, P., ... Gosain, K. (2012). Application of the Building Block Methodology to the Sri Ram Sagar Project. SINTEF Report No. TR A7181 (p. 44).

Skarbøvik, E., Udnes, H., Øgaard, A., Eggestad, H., Rohrlack, T., Tingvold, J., \& Drageseth, T. (2011). Helhetlig utredning av manøvrering og flombegrensning $i$ Vansjø. (Integrated evaluation of dam operation and flood management of Lake Vansjø; in Norwegian). Bioforsk Rapport 6(63), 60.

SRSP. (2009). Water use efficiency studies - Sri Ram Sagar Project. Book published by Irrigation and command area development department, Government of Andhra Pradesh.

Tharme, R. E., \& King, J. M. (1998). Development of the Building Block Methodology for instream flow assessments, and supporting research on the effects of different magnitude flows on riverine ecosystems. Water Research Commission Report No. 576/1/98 (p. 452).

\section{Copyrights}

Copyright for this article is retained by the author(s), with first publication rights granted to the journal.

This is an open-access article distributed under the terms and conditions of the Creative Commons Attribution license (http://creativecommons.org/licenses/by/3.0/). 